\title{
Being Isolated and Protected Is Better Than Just Being Isolated: A Case Study From the Alacranes Reef, Mexico
}

\section{OPEN ACCESS}

Edited by:

Hajime Kayanne,

The University of Tokyo, Japan

Reviewed by:

Aldo Cróquer,

Simón Bolívar University, Venezuela

Anna Roik,

GEOMAR Helmholtz Center for Ocean

Research Kiel, Germany

*Correspondence:

Fabio Favoretto

favoretto@uabcs.mx

Octavio Aburto-Oropeza

maburto@ucsd.edu

Specialty section:

This article was submitted to

Coral Reef Research,

a section of the journal

Frontiers in Marine Science

Received: 14 July 2020 Accepted: 02 October 2020

Published: 04 November 2020

Citation:

Favoretto F, Mascareñas-Osorio I, León-Deniz L, González-Salas C, Pérez-España H, Rivera-Higueras $M$ Ruiz-Zárate M-Á, Vega-Zepeda A,

Villegas-Hernández $\mathrm{H}$ and

Aburto-Oropeza O (2020) Being

Isolated and Protected Is Better Than Just Being Isolated: A Case Study

From the Alacranes Reef, Mexico.

Front. Mar. Sci. 7:583056.

doi: 10.3389/fmars.2020.583056

\begin{abstract}
Fabio Favoretto 1,2*, Ismael Mascareñas-Osorio², Lorena León-Deniz ${ }^{3}$, Carlos González-Salas ${ }^{3}$, Horacio Pérez-España ${ }^{4}$, Mariana Rivera-Higueras ${ }^{5}$, Miguel-Ángel Ruiz-Zárate ${ }^{6}$, Alejandro Vega-Zepeda ${ }^{6}$, Harold Villegas-Hernández ${ }^{3}$ and Octavio Aburto-Oropeza ${ }^{7 *}$
\end{abstract}

${ }^{1}$ Gulf of California Marine Program, Universidad Autónoma de Baja California Sur (UABCS), La Paz, Mexico, ${ }^{2}$ Centro para la Biodiversidad Marina y la Conservación A. C. (CBMC), La Paz, Mexico, ${ }^{3}$ Departamento de Biología Marina, Campus de Ciencias Biológicas y Agropecuarias, Universidad Autónoma de Yucatán, Mérida, Mexico, ${ }^{4}$ Instituto de Ciencias Marinas y Pesquerías, Universidad Veracruzana, Boca del Río, Mexico, ${ }^{5}$ Universidad Nacional Autónoma de México (UNAM), Posgrado en Ciencias del Mar y Limnología, Ciudad Universitaria, Mexico City, Mexico, ${ }^{6}$ Departamento de Sistemática y Ecología Acuática, El Colegio de la Frontera Sur, Unidad Chetumal, Chetumal, Mexico, ${ }^{7}$ Scripps Institution of Oceanography, University of San Diego, San Diego, CA, United States

Isolated reefs suffered from overfishing to a lesser extent than coastal reefs systems. Nevertheless, the exploitation of coastal areas forced fishers to move offshore to compensate for their decreasing catches, helped by an overall increase in their technological capabilities. Thus, these once pristine isolated areas are under increasing threat and should be considered a protection priority. Here, we compared the fish and epibenthic community of two isolated coral reefs in the southern Gulf of Mexico: one is the Alacranes reefs a Marine Protected Area (MPA) with two No-Take Zones (NTZs) and the other is Bajos del Norte an Open Area $(\mathrm{OA})$. Alacranes reef is $\sim 135 \mathrm{~km}$ off the northern coast of the Yucatan Peninsula while Bajos del Norte $\sim 160 \mathrm{~km}$. Our results show that despite being isolated, the OA reefs never reach the same biomass levels of MPA or NTZ reefs which in some cases exceeded 1 ton/ha. Furthermore, $70 \%$ of the reefs within NTZ and MPA had a large predatory fish (e.g., sharks, jackfish, groupers) biomass relative contribution larger than $25 \%$, while only two reefs in the OA had a relative piscivore contribution of more than $25 \%$. Large predatory fish have a larger contribution to overall biomass within NTZs than MPAs reefs, even at low biomass values, suggesting that NTZ is more effective in protecting large predators. NTZ and MPA reefs also showed from 5 to 10\% higher coral cover than OA which had a higher erect algae cover ( 22.9\%). Indicating that the disruption of the trophic pyramid caused by the fishing pressure in OA reefs is reflecting on the trophic cascades controlling the benthic communities balance. These isolated areas represent the last pillars of natural diversity and are under such an increasing anthropogenic pressure that just being isolated is not enough anymore to guarantee a safe zone from detrimental activities like overfishing. Immediate establishment of protective NTZ is needed to maintain the role they play as a natural wilderness capital.

Keywords: no-take areas, overfishing, fishing down, trophic pyramids, trophic cascades 


\section{INTRODUCTION}

Protecting the last wild marine places in the world is a crucial step necessary to preserve biodiversity and achieve international goals like the United Nations Sustainable Development Goal n. 14, Life Below Water. In this context, Marine Protected Areas (MPAs) are important protection tools, but are effective only when they are either: No-Take, well-Enforced, Old, Large, and Isolated (NEOLI, Edgar et al., 2014).

Some oceanic islands have the natural benefit of being geographically isolated, which limited direct human negative interactions, like overfishing and pollution; which are known to undermine reef communities in their coastal counterparts (e.g., Friedlander et al., 2014; Smith et al., 2016; McClanahan et al., 2019). Indeed, isolated islands are considered to be among the last standing places where human influence had not a significant effect (e.g., Williams et al., 2011; Edwards et al., 2013; Friedlander et al., 2013, 2014; McClanahan et al., 2019). Isolated locations are also of high biodiversity value by hosting endemism of flora and fauna and are of general biogeographic and connectivity interest (e.g., Victor and Wellington, 2000; Robertson, 2001; DeMartini and Friedlander, 2004; Friedlander et al., 2019).

However, fishery technology has developed swiftly, easing the effort of reaching these remote areas in search of a profit (Kroodsma et al., 2018; Tickler et al., 2018). This coupled with the degradation of the coastal fishing grounds pushed fishers to move further offshore to compensate for their landings (Bhathal and Pauly, 2008; Liang and Pauly, 2017). Therefore, the economic interest on remote places will continue to increase, threatening these last pillars of wilderness (Coghlan et al., 2017).

Direct impacts, such as overfishing are driving the removal of key species from a functional standing point. For example, herbivorous fish (e.g., parrotfishes) are removed when the fishing pressure have been long affecting the reefs; and macroalgae respond quickly to the decrease in fish biomass (McClanahan et al., 2011). The disruption of the trophic balance in the reefs can lead over time to a phase-shifts, were palatable macroalgae, relieved from the herbivores grazing pressure, can overgrow corals (Steneck et al., 2017) and lead to a reduction in tridimensional complexity of the reefs which often translates to a loss in overall biodiversity (e.g., Cheal et al., 2010).

In the Southern Gulf of Mexico, there are several banks or platform reefs belonging to the Campeche Bank Reef System, many poorly explored. The largest of these formations is the Alacranes (Spanish for scorpion) reef $\left(\sim 650 \mathrm{~km}^{2}\right)$, its name alluding to the danger the reef posed to vessels, with histories of wreckages starting from the Spanish colonization of Mexico. Located $\sim 135 \mathrm{~km}$ off the northern coast of the Yucatan Peninsula, it is formed by massive coral reefs with a semi-elliptic shape over which form five small keys (Figure 1).

The Alacranes reef was designated a National Park in 1994, is part of UNESCO's Man and the Biosphere Program (MABUNESCO), and the islands are also Ramsar Sites and Important Bird Area (IBA). Within the National Park, two areas are designated as No-Take Zone (NTZ) (Figure 1) where no fishing is allowed. Human activity in the park is low and mostly concentrated on the southern island (Isla Perez).
Commercial and sport fishing is allowed and active in the Alacranes reef, according to the MPA management plan (SEMARNAT-CONANP, 2007), and targets lobsters (Palinurus argus), parrotfishes (Scaridae), snappers (Lutjanidae), and groupers (Epinephelidae) for either profit or subsistence. Overfishing and illegal fishing are common problems of the area even in the zones that are designated as NTZ due to low compliance and weak regulations. Sharks, large fishes, turtles, mollusks, among other species where extensively fished in the Alacranes reef area (Tunnell et al., 2007). Twenty-nine species of sharks and rays were recorded in the Alacranes reef, but an active artisanal fishery lead them to commercial collapse in the 90's (Beaver and Chávez, 2007).

However, its remoteness has in some way lessened the reef's exposure to the unsustainable pressure suffered by coastal reefs of the same system. For example, many reefs of coastal Veracruz are experiencing severe degradation, along with many other reefs along the Yucatan Peninsula that also have the added pressure of a high-density human presence that bring along issues involving pollution and coastal modification (Tunnell et al., 2007; Brenner et al., 2018; Arguelles et al., 2019; Gil-Agudelo et al., 2020; HortaPuga et al., 2020).

To compare the benthic and fish community in Alacranes reefs, we included in our study area the Bajos del Norte reefs. This is an isolated reef further away from the coast than Alacranes and is made up of a series of coral mountains. Since it is further away from the coast, the Bajos del Norte is thought to host a healthier reef community then Alacranes, thanks to its isolation. The objective of our analysis was to compare reef health indicators that can be linked to direct human impacts, in particular to overfishing. Humans often disrupt natural communities in predictable ways, for example, by preferentially target specific fish trophic levels during fishing activities (Darimont et al., 2011). Usually, community structure can be described by the relative change in the shape of the "Eltonian" pyramid of biomass, which represent how total biomass is distributed at different trophic levels in the food chain (Elton, 1927; Odum, 1955; Trebilco et al., 2013). The pyramid often exhibits a consistent shape, called the trophic structure, becoming systematically more bottomheavy as pyramid size increases along a biomass gradient. Where overall reef fish biomass is high, and fishers are not selectively removing higher trophic level individuals, a concave trophic distribution emerges. The concave distribution implies a more direct link between lower and upper trophic levels, which may confer greater energy efficiency. This trophic distribution usually emerges when community biomass exceeds $\sim 650 \mathrm{~kg} / \mathrm{ha}$ or $\sim 0.65$ ton/ha (Graham et al., 2017), suggesting that fisheries for upper trophic level species will only be supported under lightly fished scenarios. These frameworks usually involve the use of medium to large scale data (McClanahan et al., 2011; McClanahan, 2014; Aburto-Oropeza et al., 2015; MacNeil et al., 2015; McClanahan and Graham, 2015). In this study, we apply it on a small-scale by considering each transect as representative of a particular section of the reef. We expect to have sections the transect is describing that are less productive due to local factors and sections the transect describes with high productivity which translates to high biomass of fishes. 


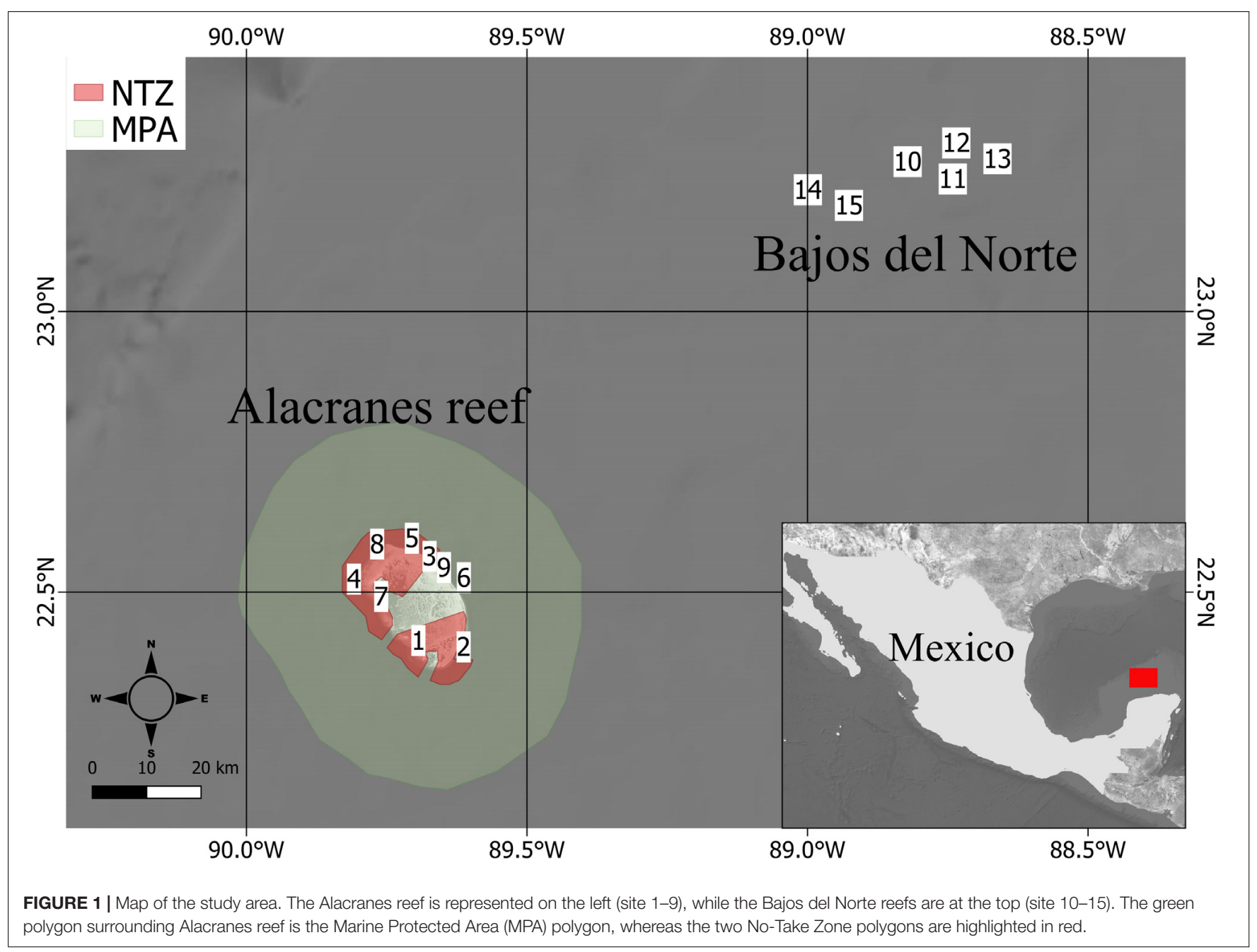

The results of our assessment serve as a modern baseline to evaluate further changes in the community structure of the reefs that might arise from an improved protection of the area. We hope that this study will stimulate an effort to increase protection of the area as well as supporting the creation of a large reserve network of the Campeche Bank Reef System (Gil-Agudelo et al., 2020).

\section{MATERIALS AND METHODS}

\section{Field Survey}

Sampling sites around Alacranes and Bajos del Norte reefs incorporated representative wave exposure, habitats, and oceanographic conditions (Figure 1). Since Bajos del Norte reefs does not emerge from the water, to compare sites with Alacranes we chose a similar depth for all the sites of ca. 10-15 $\mathrm{m}$. Therefore, the sites not showing that depth range were disregarded since, on this depth range, both Alacranes and Bajos del Norte have similar topography of the seascapes (see Supplementary Figure S5). Transects were randomly positioned on the reef parallel to the isobath. Characterization of the fish community was conducted by one diver counting and estimating the lengths of all the fishes encountered over four replicates of a $50 \mathrm{~m}$ long and $5 \mathrm{~m}$ wide belt area over the transect during two passes $\left(250 \mathrm{~m}^{2}\right.$ total). All conspicuous fish ( larger than $20 \mathrm{~cm}$ in total length) were counted and measured, then on the swim back along the transect line all cryptic fishes were counted. All fishes were identified to the species level. Fish total length was estimated to the nearest $\mathrm{cm}$ and individual specific lengths were converted to body weights. The numerical density was expressed as a number of individuals per $\mathrm{m}^{2}$ and then biomass density was expressed as ton per ha. The biomass of individual fishes was estimated using the allometric length-weight conversion $\mathrm{W}=\mathrm{aTL}^{\mathrm{b}}$, where parameters $\mathrm{a}$ and $\mathrm{b}$ are species-specific constants, TL is the total length in $\mathrm{cm}$, and $\mathrm{W}$ is weight in grams. Length-weight fitting parameters were obtained from FishBase (Froese and Pauly, 2019). The cross-product of individual weights and numerical densities was used to estimate biomass density by species. Fishes were then categorized into four trophic groups (piscivores, carnivores, herbivores, and zooplanktivores) according to their trophic level after Harmelin-Vivien (Harmelin-Vivien, 2002). These categories were further organized in trophic guilds according to differences 
in functionalities of the fishes (see Supplementary Table S1). Here we named these trophic guilds as functional groups.

On the same transect used for the fish community, the characterization of the benthos was conducted along four replicates of a $50 \mathrm{~m}$ long transect parallel to the larger axis of the reef at each site. For algae, corals, and other sessile invertebrates we used a line-point intercept methodology along transects, recording the species or taxa found every $50 \mathrm{~cm}$ on the measuring tape. Point contact data were expressed as percent cover. All benthic records where divided by functional groups. In the case of macroalgae, we followed the classification suggested in Steneck and Dethier (1994) by dividing taxa in Articulate Coralline Algae (ACA, e.g., Amphiroa spp.), Crustose Coralline Algae (CCA, e.g., Lithophyllum spp.), Corticate (e.g., Sargassum spp.), Corticate Foliose (e.g., Lobophora variegata, Dictyota spp., Padina spp.), Erect Algae (e.g., Caulerpa spp.), Foliose (e.g., Anadyomene spp.), Microalgae (Cyanobacteria spp.), and Turf (all algae $<2 \mathrm{~cm}$ ). For the invertebrates, we divided them in the following functional groups: Fan Corals (e.g., Antillogorgia spp., Eunicea spp., Gorgonia spp.), Digitate (e.g., Madriacis spp.), Massive Coral (e.g., Motastrea spp.), Ramified coral (e.g., Millepora spp.), and Porifera (e.g., Aplysina spp.).

\section{Community Description}

In this rapid assessment, we were most interested in assessing the health of the reef system. Therefore, we focused on functional groups using cover and biomass as indicators of health. Nevertheless, we did the same statistical comparisons on functional groups at a taxa and species level. For benthic taxa, we used cover as a descriptive variable, and in the case of fishes we also used abundance. Results were similar to the ones obtained with functional groups thus we decided to focus on those.

In our analysis we used the reefs as a factor (two levels: Alacranes-MPA and Bajos del Norte-OA) and the wind exposure as a proxy for major differences in seascapes (two levels: Leeward and Windward). Furthermore, we wanted to test differences between the different protection levels that are in place by sorting all the reefs by the sites within core areas where fishing is prohibited No-Take Zones (NTZ), sites under the Alacranes Reef National Park Marine Protected Areas (MPA), and finally the sites with no protection as Open Areas (OA).

We used univariate ANOVA to test for differences for each benthic and fish functional groups among the different protection levels (NTZ, MPA, OA) separately. ANOVA assumptions were tested both visually over residuals and through Shapiro's test (Normality) and Levene's test (homogeneity of variance). When deviation from normality were found we applied a $\log (\mathrm{x}+1)$ transformation to data. When significant differences were found, a post-hoc Tukey-HSD pairwise comparison was applied. The Tukey-HSD test itself considers multiple comparisons similarly to the Bonferroni correction, but it is a test of its own and depends on no other correction for multiple comparison. This test was made using the "tukeyHSD()" function in the package "stats" v. 4.02 of the R programming language.
We categorized the trophic index of each fish species by creating 5 levels of 0.5 range from 2 to 4.5 to create trophic levels. We then calculated species richness (count) and diversity indexes (Shannon and Simpson) for each trophic level. We then tested differences between richness and diversity indexes among the different protection levels (OA-MPA-NTZ) using ANOVA. We were interested in testing the interaction of the two terms (richness or diversity indexes vs. protection levels) to determine significant changes of a particular trophic level among protection levels. We did not perform this analysis on the benthic species because of the use of many functional group surrogates to direct species identification, especially for macroalgae, since the benthic monitoring was mostly aimed at a functional representation of the seascapes.

To test whether there are differences in the reef assemblages (benthic and fish communities) between reefs (Alacranes-MPA and Bajos del Norte-OA) and exposure (Leeward and Windward) we performed a permutational multivariate analysis of variance. Factor were treated as fixed and exposure was nested within the reefs factor. Similarly, we tested the effect of protection levels (fixed factor) on benthic and reef fish assemblages.

Both tests were computed using the "adonis2" formula available in the package "Vegan" v.2.5-6 (Oksanen et al., 2019) built with the R programming language (R Core Team, 2018). For the test we used 9999 permutations and the Bray Curtis distance matrix. The formula partition sums of squares of a multivariate data set, and is directly analogous to MANOVA (multivariate analysis of variance) (Anderson, 2001). This test treats nestedness of factors by constraining the permutations to those groups.

Where significant interaction was detected, pairwise comparisons of each level of protection were tested with a percentage similarity analysis (SIMPER). The SIMPER test was used to identify the average similarity within, and the dissimilarity among, benthic and reef fish functional group assemblages.

The SIMPER was calculated using the "simper" formula available in the R package "Vegan" v.2.5-6 (Oksanen et al., 2019). Then, the functional community matrix was standardized, and Hellinger transformed before the Principal Component Analysis (PCA) to avoid the double zero problem (Legendre and Gallagher, 2001). The PCA results were then plotted to visualize patterns of benthic and fish functional groups assemblage structure among sites.

\section{Trophic Structure}

In this study, we apply the trophic pyramid framework on a small-scale by considering each transect as representative of a particular section of the reef. We expect to have sections the transect is describing that are less productive due to local factors and sections the transect describes with high productivity which translates to high biomass of fishes. In this rationale, we want to include the variability of all the transect representing the variability of the system under the hypothesis that two comparable systems should show similar gradients in biomass from low to high, and that the trophic levels have similar contributions to these gradients. We assume that most of the differences in the higher trophic levels can be associated with 
overfishing since other known human stressors (e.g., pollution, river discharge, sedimentation) are not relevant to this study area.

To inspect the biomass gradient, we calculated the proportion of each trophic level category and plotted the $\log (x+1)$ of fish biomass found in each transect in the study area, and within the three protection levels, against the relative proportion of each of the trophic level category within the same transect. To visualize the change in the relative and log biomass of these trophic levels across the biomass gradient, we fit first-order polynomial trend lines to the data. Then we constructed trophic pyramid shapes based on thresholds of log biomass $(0-0.25,0.25-0.5,0.5-1,>1)$. We then examined the different pyramid shapes within each biomass threshold using relative biomass proportion by each trophic level category.

\section{RESULTS}

\section{Macroalgae}

We found a total of 14 macroalgae taxa. The most common functional group was corticated foliose algae with an overall cover of $27.4 \%$ (St. Err.: \pm 0.17$)$, then erect algae $(22.9 \% \pm 1.1)$, turf algae $(13.0 \% \pm 0.3)$. With a lower cover followed foliose algae $(8.5 \% \pm 0.2), \mathrm{CCA}(6.2 \% \pm 0.1), \mathrm{ACA}(5.1 \% \pm 0.2)$, and corticated algae $(4.5 \pm 0.6)$. The species we found more frequently was Lobophora variegata (a corticated foliose) with an average contribution to overall reefs cover of $42.9 \%( \pm 0.2)$, then Stypopodium zonale $8.4 \%( \pm 0.2)$, and Dictyota sp. $8.4 \%( \pm 0.1)$. Cover of functional groups differed among protection levels (Figure 2A). We found significative differences among functional groups of corticated foliose which were significantly lower in OA compared to MPA or NTZ (Table 1). Erect algae were only present in OA, turf algae were significantly higher in MPA areas than OA but were not significantly different between the other pairwise comparisons (Table $\mathbf{1}$ ).

\section{Invertebrates}

We found 67 invertebrate taxa, 23 porifera, 21 massive corals, 10 fan corals, 6 digitate corals, 2 ramified corals, and 5 anemones. Overall, fan corals had the highest cover with $12.3 \%$ $( \pm 0.1)$, followed by ramified corals $(5.15 \% \pm 0.1)$, massive corals $(4.3 \pm 0.1)$, sponges $(4.3 \% \pm 0.1)$, and digitate corals $(3.4 \% \pm 0.08)$.

On a species level, Monastraea cavernosa was the most common at $7.4 \%( \pm 0.08)$ of the total number of invertebrate species, then Palythoa caribaeorum $(6.5 \% \pm 0.5)$, and the ramified hydrocoral Millepora alcicornis $6.5 \%( \pm 0.3)$. These were followed by the fan corals Antillogorgia americana $(5.9 \% \pm 0.2)$ and Pseudoplexaura sp. $(5.5 \% \pm 0.4)$, and finally the digitate corals Madracis auretenra $(5.5 \% \pm 2.6)$ and Madracis formosa $(5.1 \% \pm 0.4)$. Cover of coral functional groups differed among the three protection levels (Figure 2A), where fan corals and ramified corals had significantly higher cover in MPA than OA or NTZ. No significant difference was found in digitate or massive coral cover.

\section{Fishes}

We identified a total of 112 fish species from 30 families during the expedition. We found a total of 96 species within the MPA and 84 in the OA reefs, but no significant differences were found in richness among protection levels. We did find differences in fish functional groups among protection levels (Figure 2B). Piscivores were significantly higher in NTZ and MPA than OA, while browsers were significantly lower in the NTZ than MPA and OA. We also found a significant difference in piscivore biomass between NTZ and MPA, but the $p$-value was close to the significance threshold (Table 1). Finally, planktivores were significantly lower in MPA than NTZ or OA. Sites within NTZ and MPA areas showed reefs with higher mean biomass than

\section{A}

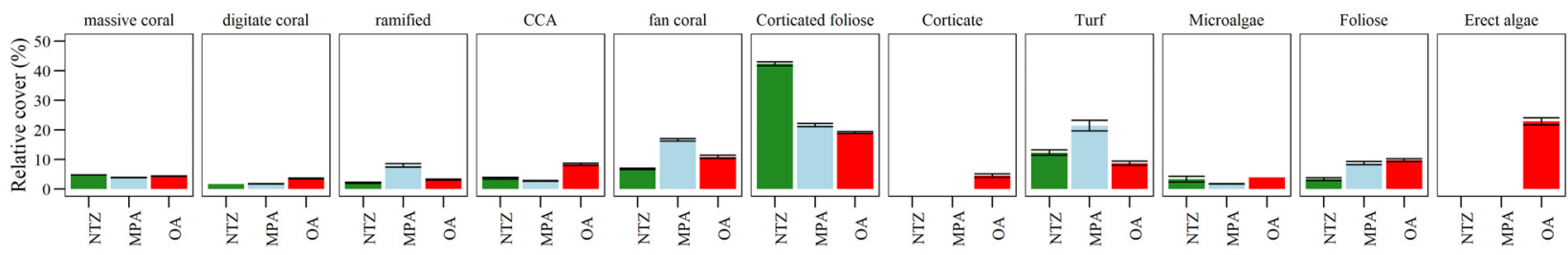

B
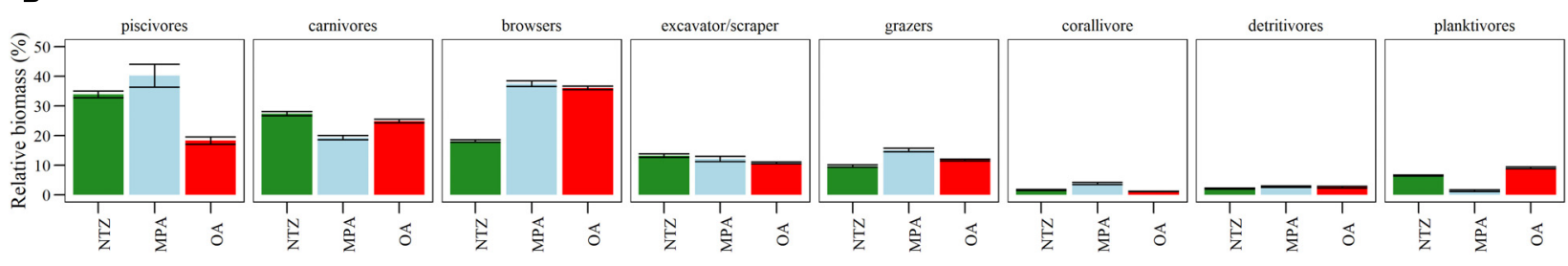

FIGURE 2 | Differences between different protection levels (NTZ stands for No-Take Zone, MPA is Marine Protected Area, OA is Open Area) comparing: (A) Mean relative cover of main benthic macroalgae (capitalized) and coral (not capitalized) functional groups ordered by what is linked to good reef health toward groups associated with degradation; (B) mean relative biomass of fish functional group. Error bars represent standard error of the mean. 
TABLE 1 | Univariate comparisons of benthic functional groups among different protection levels where NTZ is No-Take Zone, MPA is Marine Protected Area, $\mathrm{OA}$ is Open Area.

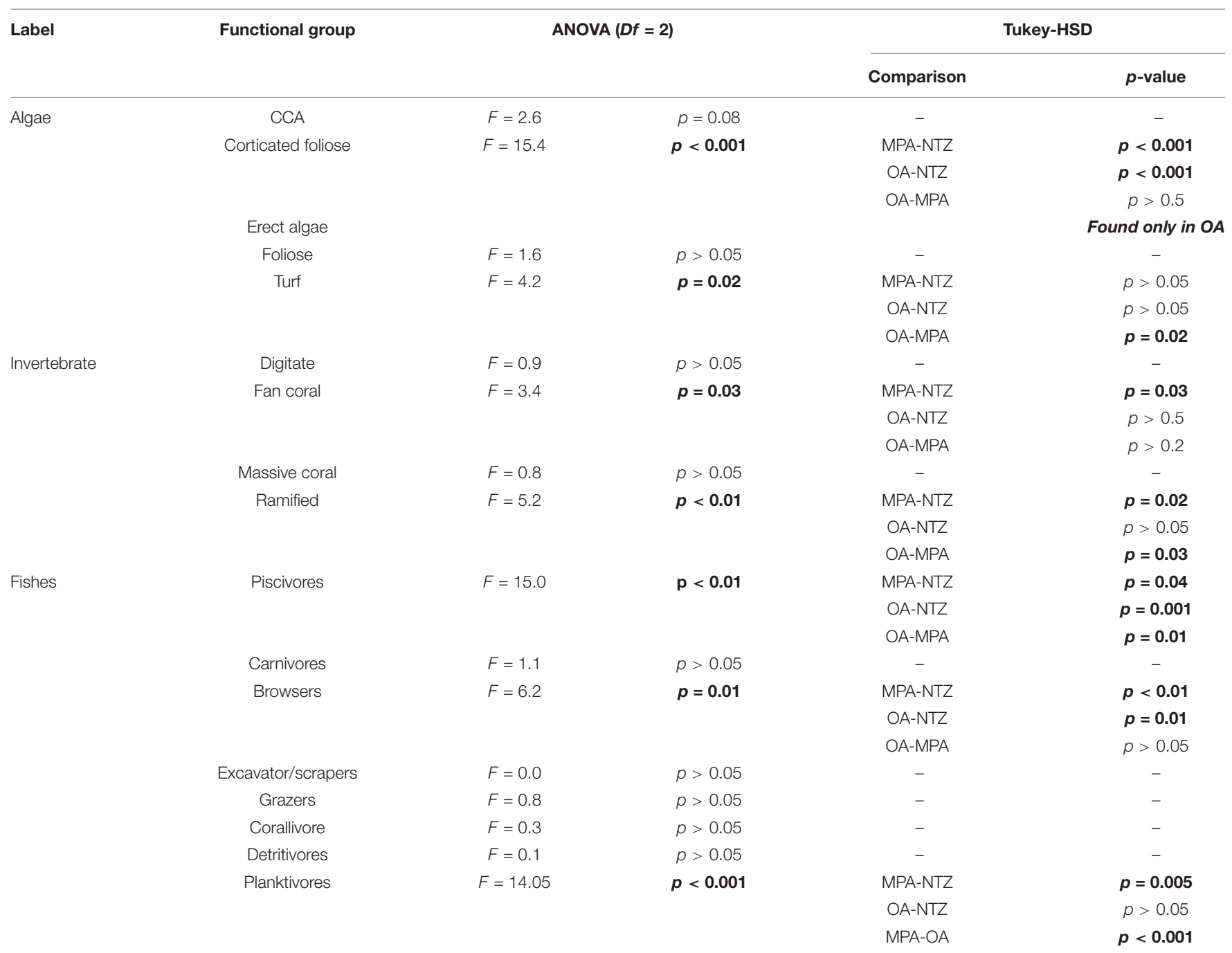

Each functional group of macroalgae and invertebrate was tested using ANOVA and if the test was significant ( $p<0.05)$ a post-hoc Tukey-HSD test was made for pairwise comparison. In bold are significant $p$-values.

those in $\mathrm{OA}$, the difference is mostly at the piscivore level (Figure 3). As relative contributions, 70\% of the reefs within NTZ and MPA had a piscivore biomass relative contribution larger than $25 \%$, while only two reefs in the OA had a relative piscivore contribution of more than $25 \%$.

\section{Community Structure}

We found differences in richness and diversity indexes among the different protection levels and the trophic levels (Figure 4). In particular, we found higher top predator (upper trophic levels, 4-4.5) richness and diversity (Figure 4) in NTZ, as well as other larger trophic levels from $3-3.5$ to $3.5-4$. The community structure of macroalgae, invertebrates, and fishes was different between the island (Alacranes-MPA reef and the Bajos del Norte-OA) and the wind exposure (Leeward and Windward) of the reefs. In particular, we found significant differences in the interaction term of reefs* exposure (Supplementary Table S3).
We also found differences among the three protection levels. The multivariate analysis showed significant result in the comparison among protection levels $(F=6.4, p=0.001)$, and the SIMPER pairwise comparisons suggested an important role of macroalgae functional groups in discriminating between OA, MPA, and NTZ (Supplementary Table S4). These differences are shown by the PCA plot with two significant axes that explained $24.87 \%$ and $16.99 \%$ of the variance, respectively (Figures 5A,B). The ordination separates the sites into three main groups which correspond to the three levels of protection: OA, MPA, and NTZ (Figures 5A,B).

On the first PCA axis, OA reefs are characterized by four algae loadings: erect algae, ACA, corticate algae, and foliose algae. Digitate corals and CCA have also some influence on these reefs (Figure 5B). On the other side of the gradient, protected sites, and mostly the ones within NTZs are characterized by corticated foliose and turf algae. As for the 

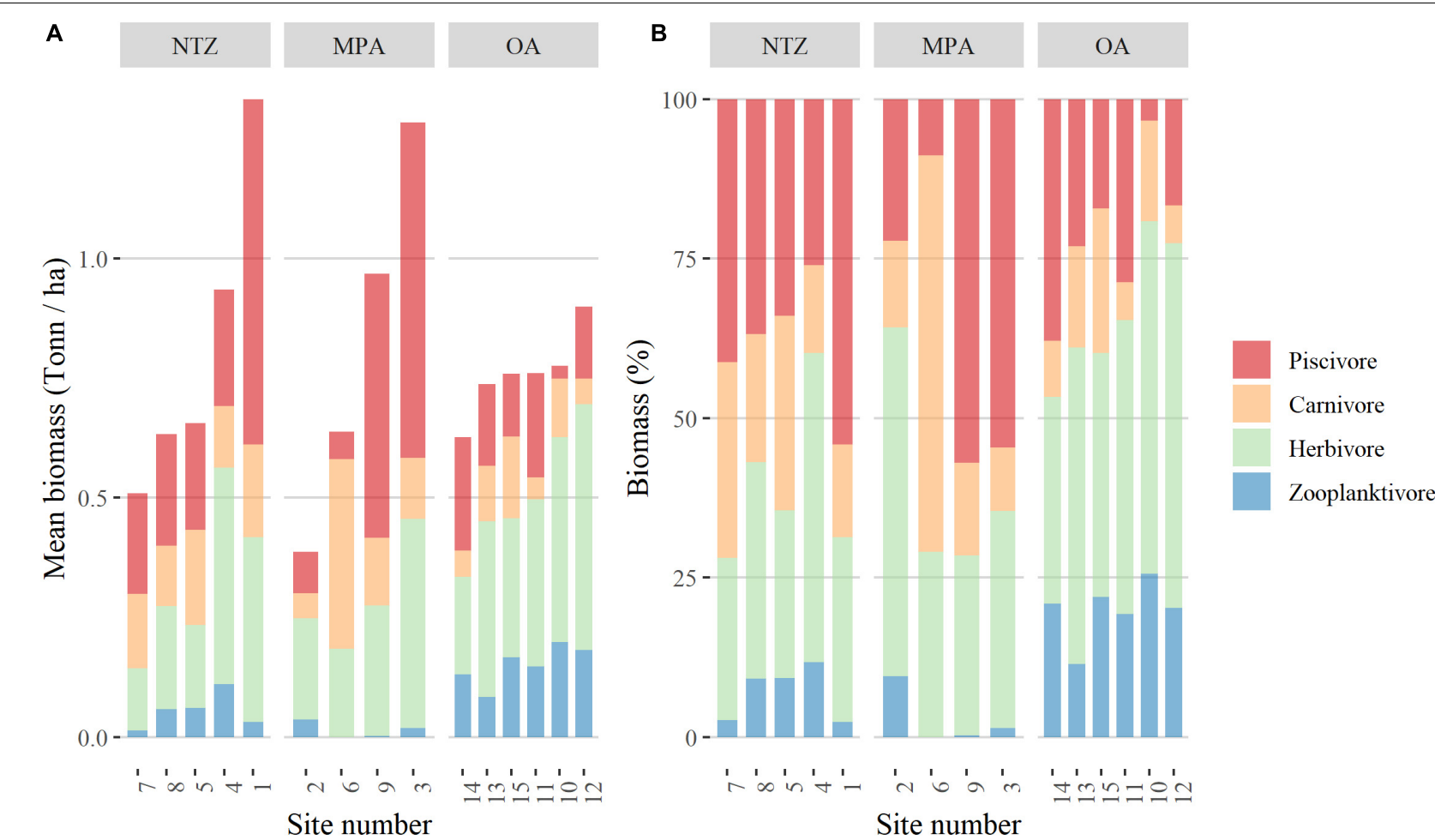

FIGURE 3 | Contribution of fish trophic groups on the different reefs as (A) mean biomass (Ton/ha) and (B) relative contribution in \%. In the three protection levels: NTZ is No-Take Zone, MPA is Marine Protected Area, OA is Open Area.

invertebrates, the massive coral functional group characterizes the NTZ reefs which are also related to the corallivore fish group. Piscivores also characterizes the NTZ, having a higher biomass in those reefs.

On the second PCA axis (Figure 5), a second gradient is highlighted which separates MPA sites from the rest. Mainly ramified and fan corals are the cause of this separation as well as carnivore fish but in an opposite fashion. Interestingly, the piscivore and carnivore fish loadings seems to be unrelated due to their orthogonal position in the ordination. On a summary note, $O A$ reefs have higher macroalgae cover, whereas protected areas (NTZ+MPA) show higher coral and corticated foliose algae as well as higher massive coral cover and piscivore abundance.

\section{Trophic Pyramid Structure}

By analyzing the fish community within each transect of our survey, it is possible to identify a gradient in the fish biomass (Supplementary Figure S1). The associated trophic structure changes accordingly from transects with low biomass dominated by lower trophic levels toward transects with higher overall biomass where higher trophic levels (4-4.5) are dominant (Supplementary Figure S1). The fish community structure in OA sites do not reach the same high biomasses as NTZ and MPA sites. Large predators (upper trophic levels) never dominate the biomass as they should in the OAs, and overall biomass is never higher than a 1.0 threshold of biomass in a log $(x+1)$ scale (Supplementary Figure S3).
It is possible to see that NTZ have a higher proportion of upper trophic level overall than OA (Figure 6 and Supplementary Figure S3). Furthermore, the trophic pyramid in NTZ reefs always has high contributions of large fishes to the overall biomass (Supplementary Figure S3). MPAs also has a higher proportion large predators (higher trophic levels) but is somewhat more variable than NTZs (Supplementary Figure S3). Differences in the OA, MPA, and NTZ reefs trophic pyramids stands in the contribution of large predators (higher trophic levels, 4-4.5) and the smallest planktivores (low trophic levels 22.5) (Figure 6A). Similarly, the trophic structure of the Alacranes reef compared with Bajos del Norte show a higher proportion of the top predators (Figure 6B).

\section{DISCUSSION}

Remote reefs have suffered from human impacts to a lesser extent than coastal reefs, especially when it comes to overfishing (Graham et al., 2017).

However, the depletion of the coastal fishing grounds, coupled with the overall improvement of fishing technological capabilities, allowed fishers to move further offshore once their target species is depleted from areas near the coast (Bhathal and Pauly, 2008; Liang and Pauly, 2017). Thus, these once pristine remote reefs are now suffering increasing pressures and should be considered a priority for protection. In the Campeche Bank Reef System, many remote reefs are yet to be described. One 

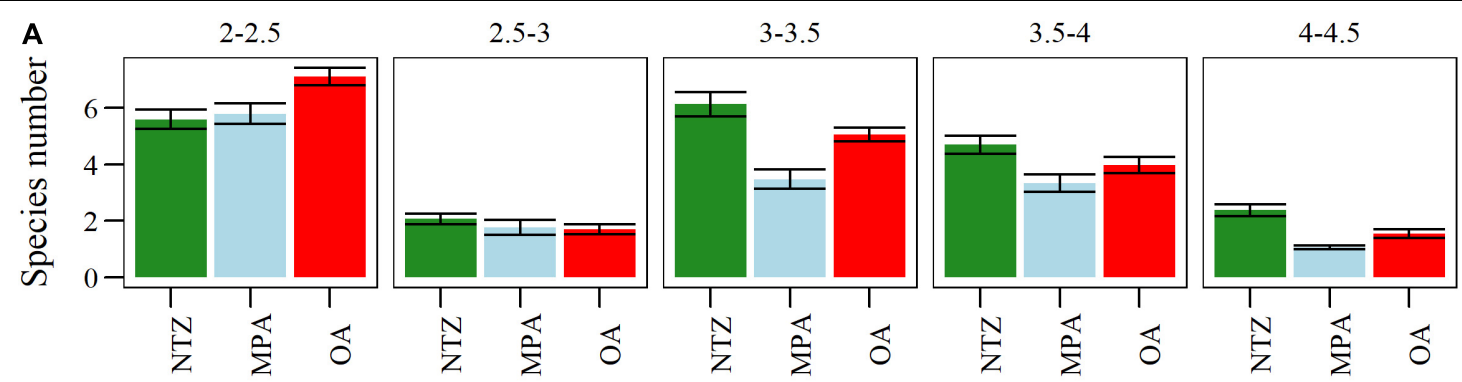

B
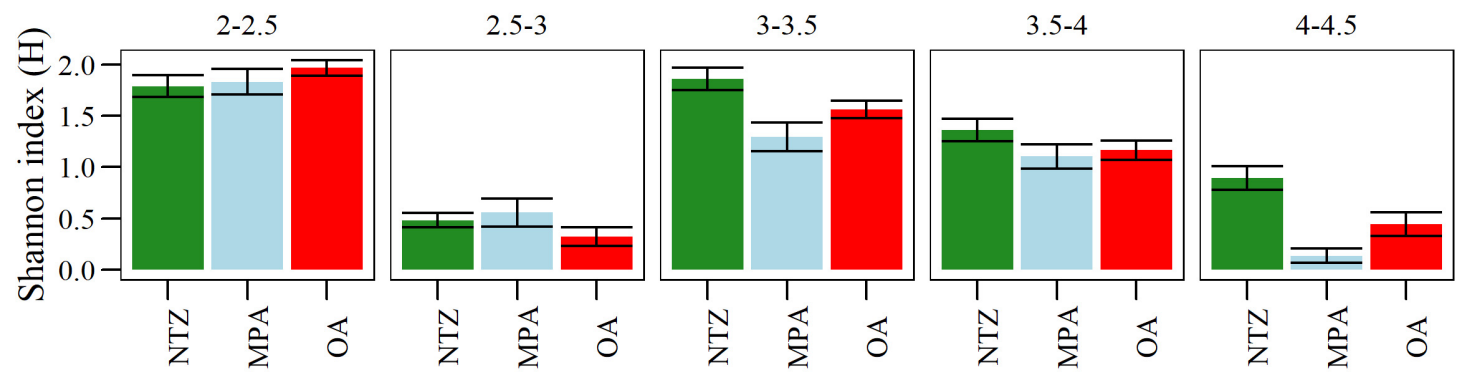

C
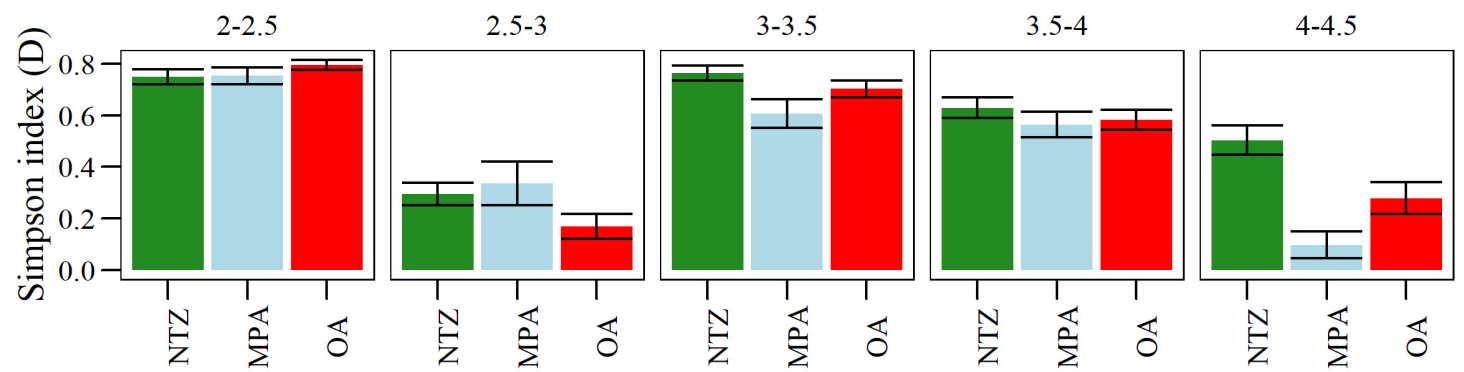

FIGURE 4 | Fish species number (A) and Shannon (B) and Simpson (C) diversity indexes at the different protection levels (NTZ is No-Take Zone, MPA is Marien Protected Area, OA is Open Area) and trophic levels.

of these, Bajos del Norte, was described here for the first time. Due to a large number of knowledge gaps in the distribution of coral reefs in the southern Gulf of Mexico there is a need to describe new coral formations (Gil-Agudelo et al., 2020). These reefs may represent the last standing healthy reefs in the region and can function as species reservoirs for the larger reef system (Tunnell et al., 2007; Gil-Agudelo et al., 2020). While the oceanic locations of the reefs in the Campeche Bank Reef System avoid most direct human impacts like pollution and sedimentation, they still experience the effects of anchoring and overfishing as main stressors, as well as pollution associated with oil platform construction and operations (Tunnell, 2010). Therefore, these remote locations, despite their higher relative health, are threatened and undergo environmental degradation when not properly managed.

In this paper, we show that remoteness alone does not guarantee protection from overfishing, as the Alacranes reef MPAs and NTZs showed a healthier community than the Bajos del Norte OA reefs. Further, the different protection levels established on Alacranes reefs suggest that the implementation of a fully protected MPA as well as stricter surveillance would have larger benefits. In fact, despite Alacranes being a relatively healthier system than Bajos del Norte, its overall biomass was still low compared to previous studies in other areas (Newman et al., 2006), suggesting a certain degree of overfishing is still happening on the Alacranes reefs. Therefore, considering the Alacranes reef as healthy overall might mean falling into a shifting baseline syndrome (Pauly, 1995).

\section{Benthic Community Structure}

The health of a reef system can be evaluated by the relative cover of coral vs. macroalgae; according to existing reefs health indicators (e.g., see http://www.healthyreefs.org/cms/healthyreef-indicators/), coral cover is in critical condition when it is $<5 \%$ and very good when $>40 \%$. In Alacranes, coral cover has been reported to decrease from around $40-50 \%$ 


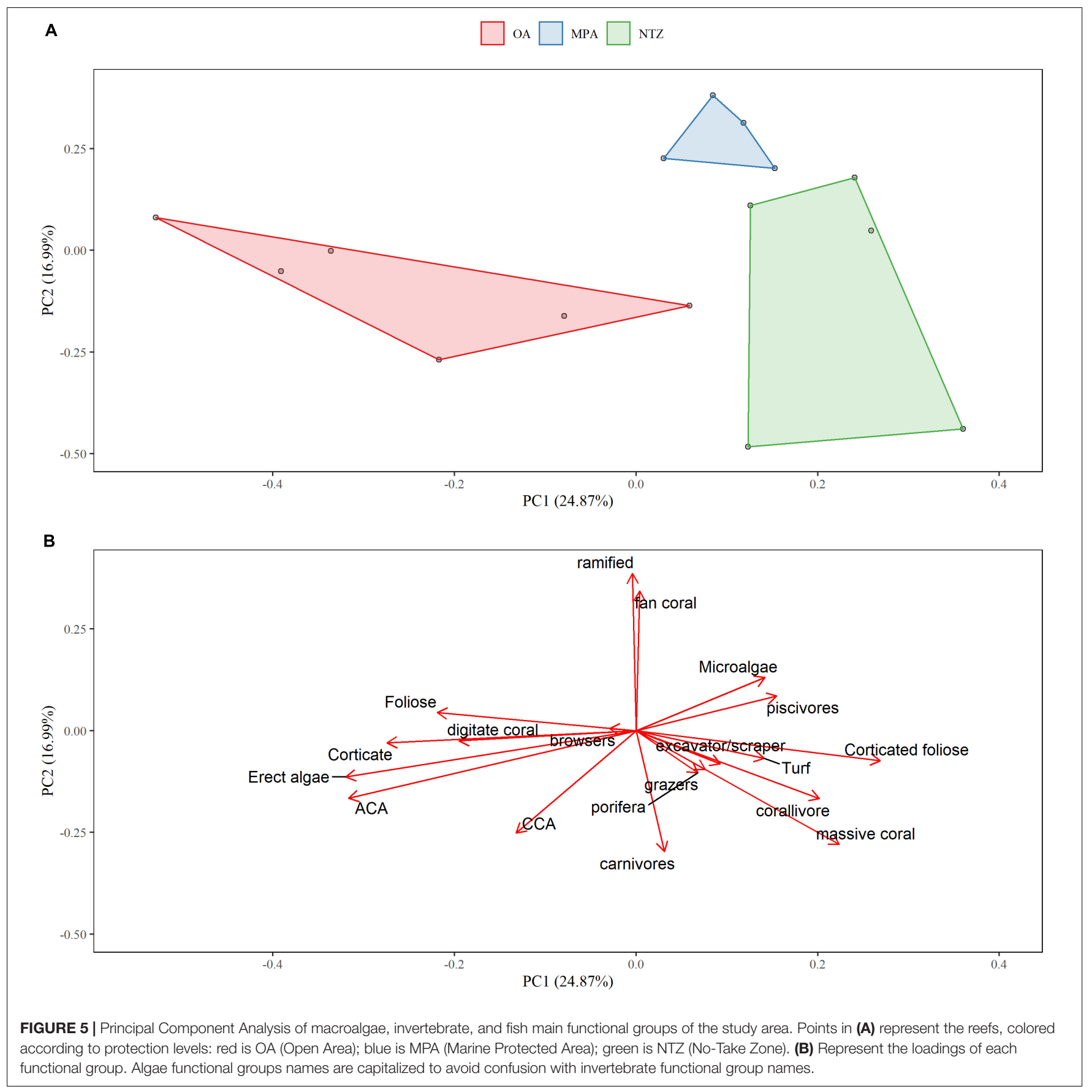

in the 1960s (Kornicker et al., 1959; Logan et al., 1969) to just $\sim 10 \%$ at present (Hernández-Landa and Aguilar-Perera, 2019; Gil-Agudelo et al., 2020). Therefore, the Alacranes reefs shifted over time from a "very good" state to a "fair" one according to these indicators. Previous studies suggest that with a $\sim 10 \%$ coral cover, Alacranes still has a good balance between the coral-macroalgae component (Hernández-Landa and Aguilar-Perera, 2019). In our more recent survey however, we reported a lower coral cover overall for the Alacranes reef $(4.19 \% \pm 3.15)$ and the Bajos del Norte $(3.07 \% \pm 1.99)$. However, our estimates do not include shallower or deeper areas where coral cover might be higher. According to our data, among the invertebrates, fan corals dominate the reefs followed by ramified and massive corals (Figure 2) but there are significant differences among the protection levels and mostly between Bajos del Norte and Alacranes (Figure 2) which suggests that protection plays a role in preserving the balance between macroalgae and coral reefs. A remarkable observation is that we did not registered any coral with the stony coral tissue loss disease, a coral plague that is affecting severely the Florida and Mesoamerican Reef Barrier coral reefs (Alvarez-Filip et al., 2019). 


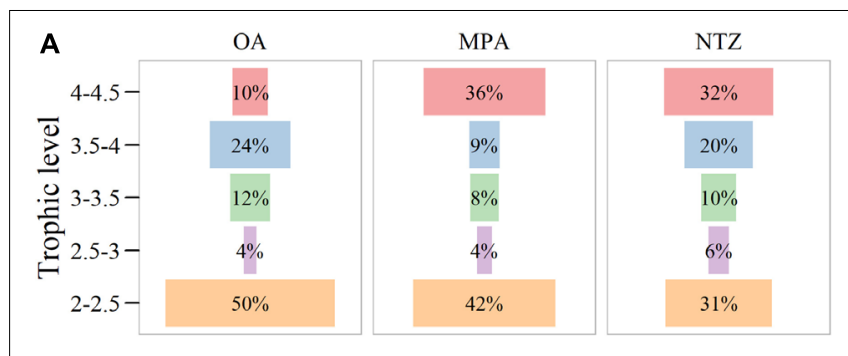

B

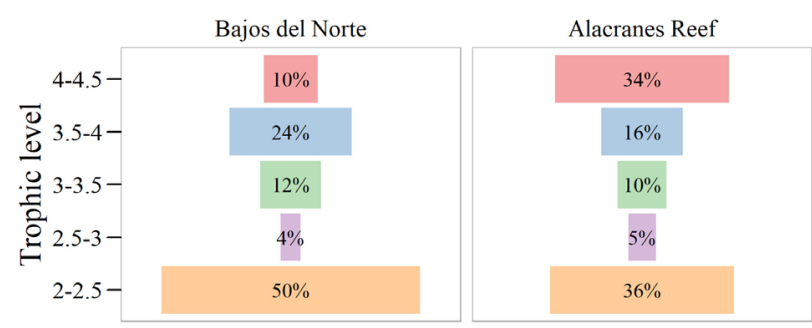

FIGURE 6 | (A) Mean trophic pyramid shape at the different protection levels and $(\mathbf{B})$ on the two studied areas: Bajos del Norte which is the Open Area $(\mathrm{OA})$ and Alacranes reef which has Marine Protected Areas (MPA) and No-Take Zones (NTZ) reefs.

Among macroalgae, different taxa and functional groups have different susceptibility to fish grazing and serve as important indicators to discriminate different processes that might occur. The dominance of macroalgae over all the reefs surveyed (Figure 2) might suggest that the reefs shifted from a coral dominated to a macroalgae dominated system. However, by splitting the macroalgae in functional groups, the dominant group was the corticated foliose, to which the highest contributor was the algae Lobophora variegata. The corticated foliose group is known for its low palatability (Paul and Hay, 1986) and its success can be associated more to a decrease of competition for substrate space with other species, like corals, than a reduction in grazing (Diaz-Pulido et al., 2009). In particular, high abundances of L. variegata are not necessarily related to low reef health (Vieira, 2020). Nevertheless, the genus is characterized by a large species variation and more studies are needed to assess the dynamics of $L$. variegata and corals in our study area. Recent studies found a particularly healthy herbivore community in Alacranes when compared to areas with higher anthropogenic disturbance (Hernández-Landa and Aguilar-Perera, 2019). Large parrotfishes were reported feeding intensively on the surface covered by turf, on the reef crest, and on adjacent areas (Hernández-Landa and Aguilar-Perera, 2019). Our data confirm that high biomass of fish excavators, scrapers, and grazers are associated with turf algae and corticated foliose algae (Figure 5) in the Alacranes reef. While sea urchins are relevant in many reefs system, in the Alacranes reef, they only accounts for $9 \%$ of the total grazing activity whereas fish herbivores account for as much as $90 \%$ (Paul and Hay, 1986; Hernández-Landa and Aguilar-Perera, 2019). Thus, on reefs with undisturbed fish communities, these excavators, scrapers, grazers, browsers remove up to $90 \%$ of the net algal production (Ferreira et al., 1998; Bonaldo et al., 2014). However, the removal of herbivorous fish by fishing, the pressure of mass tourism, and the negative effects of coastal development (e.g., nutrient inputs and/or high sedimentation), can disrupt herbivorous fish top-down control.

Normally, important herbivores like parrotfishes (Scaridae), are removed when the overfishing pressure have been long affecting the reefs, and fishermen-once higher trophic levels that provide the best catches are depleted-shift to lower trophic levels in a phenomenon known as "fishing down" (Pauly et al., 1998). This seems to be not the case yet for Alacranes, where a healthier herbivore community is still standing (see also Hernández-Landa and Aguilar-Perera, 2019), because higher trophic levels still contributes to standing biomass (Figures 3, 6). However, in the Bajos del Norte, the biomass of fish functional groups that can provide a top-down control toward algae overgrowth seems to be insufficient. In the OA reefs of Bajos del Norte, we see a higher cover of taxa like erect and foliose algae that are palatable to herbivores (Figures 2, 5), which are negatively related with biomasses of important groups like grazers and excavator and scrapers that can hinder growth and recruitment of erect and foliose algae (Figure 5; Steneck et al., 2017).

Macroalgae have been shown to respond more quickly to decreases in fish biomass than coral cover, in particular when biomass start to be lower than 1 ton/ha (McClanahan et al., 2011). We can see that the reefs in the Bajos del Norte never showed a biomass higher than 1 ton/ha (Figure 3), thus suggesting a higher fishing pressure on these reefs that is causing the disruption of the trophic pyramid and related top-down control effects.

In our study, a gradient in benthic community structure is related to the fish functional groups. In particular, this gradient underlines that important fish functional groups that can induce top-down controls on erect and foliose algae have smaller biomasses in OA reefs, whereas, higher excavator and scrapers (e.g., Scarids) and fish grazers are related to higher cover of turf algae which can, in turn, have no significant effects on coral recruitment more than other canopy-forming erect algae, even if these can impact coral growth and tissue mortality (O'Brien and Scheibling, 2018). Thus, this gradient can be explained by different levels of exploitation, where in the NTZ and MPA reefs of Alacranes there is a healthier trophic balance not found in the OA reefs of Bajos del Norte.

\section{Fish Communities}

It is still a challenge differentiating between a reef's natural variability and human impacts due to fishing on that reef. Therefore, we separated our biomass gradients according to protection level (Supplementary Figure S1 and Figure 5) and analyzed their fish trophic structure. A healthy reference for a trophic structure is a concave pattern, where there is less biomass at intermediate positions (trophic level: 2.5-3.5) than those above (trophic level: 3.5-4) or below (trophic level: 2-2.5). Such a trophic structure indicates a community-wide trophic cascade that can be easily disrupted when poaching top-predators like sharks or groupers occur (Mumby et al., 2012).

In Alacranes, MPA and NTZ reefs demonstrate a greater overall biomass compared to OA reefs, and there is a higher 
accumulation in the upper trophic levels, whereas mid trophic levels dominate in fished reefs (Figures 6A,B). The remoteness of the Alacranes reefs is probably what helped this area in maintaining a high top-predator biomass despite the key absence of sharks. We found that in the Alacranes reefs, sections with high biomass do have a trophic structure that resemble a concave pyramid, associated to a community that is still maintaining its trophic functionality (Figure 6B). In Alacranes, sharks-which fall in the upper trophic position-were poached. Thus, the biomass of the upper trophic position in the trophic pyramid is underrepresented and should be larger. The absence of sharks makes it difficult to consider Alacranes a healthy until the functionality the sharks provided is recovered. Therefore, even if a concave shape appears in fished reefs, the removal of large predators by fisheries prevents the accumulation of biomass in the upper trophic levels. On a small scale, this translates to a system with a domination of low trophic levels, where usually sea urchins or herbivore fishes can take over.

A concave trophic pyramid means that piscivores, from the upper trophic levels, have a high relative contribution to the overall biomass and can draw energy from multiple levels of the pyramid, including the bottom levels (Graham et al., 2017). In an ideal foraging dynamic of a healthy reef, toppredator fishes (trophic level: > 3.5) are expected to have a competitive advantage compared to generalist carnivores as biomass increases, thanks to a greater diversity and variety of fish as prey (MacArthur and Pianka, 1966; Hughes, 1980). This leads to a peak in top-predators when overall biomass is high (MacNeil et al., 2015; Graham et al., 2017).

The accumulation of biomass in upper trophic levels is also promoted by the increase of species with efficient consumption rates and slow life histories, which are often also fishery targets (DeMartini et al., 2008). Therefore, the removal of large predators by fisheries hinders the accumulation of upper trophic levels and a top-heavy pyramid structure may not appear at all (OA in Figure 6A) while it does at similar overall biomasses values in unfished reefs (MPA, NTZ Figure 6A).

A high biomass accumulation on the upper trophic levels can also be promoted by energy subsidies that are not produced on the reef (Mourier et al., 2016; Trebilco et al., 2016; Morais and Bellwood, 2019). This can even create an inverted pyramid with very high upper trophic level biomasses and low contribution from low trophic levels (e.g., last biomass threshold of MPA reefs in Figure $\mathbf{6 A}$ ). When overall biomass increases, the lower trophic level is expected to be maintained since coral reefs are characterized by large-bodied species of parrotfishes, surgeonfishes, and rabbitfishes that are not consumed by midtier or carnivorous species as adults. Thus, the large base of the trophic pyramid is sustained even at high biomass thanks to the consumption of highly productive algae and detritus by these large-bodied herbivores and detritivores (McClanahan et al., 2015). The pitfall of being large-bodied, however, is to be a target for fisheries, which can cause declines in biomass when overexploited (Edwards et al., 2013). This, in turn, favors smallbodied mid-level fishes that are often invertebrate feeders (e.g., wrasse and triggerfish) that are under weaker predation pressure when total biomass is low (McClanahan and Muthiga, 2016).
Conversely, when biomass increases, these small-bodied midlevel fishes are more vulnerable to predation and their biomass declines as total and upper trophic level biomass increases (Figure 6; Ruppert et al., 2013; McClanahan et al., 2015). Therefore, the disadvantage middle trophic positions have as overall biomass increases contributes to the concave pattern observed (Figure 6), where even on a small scale, the trophic structure is still heavy on the lower levels as biomass increase (Figure 6) coherently with what was found on large scale studies (Hatton et al., 2015; Graham et al., 2017).

\section{CONCLUSION}

The Alacranes reef showed a healthier trophic structure than Bajos del Norte OA reefs. But, within Alacranes, there is variability between MPA and NTZ reefs. At this scale, this variability is difficult to associate necessarily to fishing activity over localized natural factors since in our study MPA and NTZ reefs belong to the same reef system. However, the effectiveness of NTZ can be larger than an MPA with managed fisheries and enhance a larger top-predator contribution even at lower biomasses (Figure 6A). On a 0.8 log biomass threshold, upper trophic level biomass seems to shift in a dominant position when all the transects are considered (Supplementary Figure S1). However, in NTZ upper trophic level biomass start to dominate after $0.5 \log$ biomass (Supplementary Figure S1), while in OA upper trophic level are never above lower trophic levels (Supplementary Figure S1).

Having a healthy trophic pyramid should prevent phase shifts from disruption of top-down control, and should provide more resilience of the reefs even to climate change (Mellin et al., 2016). However, resilience is not guaranteed when other stressors are acting upon the reef (Bruno et al., 2019), in this case, isolation of these remote areas should provide a better chance for a higher resilience in the future, and their proper protection should be a high priority.

Management of both MPA and fisheries could benefit from our approach underlining the nuances of the trophic perspective to assess reef health on a small scale. The upper trophic positions are valuable for fisheries but are also fundamental from an ecological perspective to maintain trophic stability. Large predators are long-lived and often comply with their function in the system as adults, which manifest in the accumulation of biomass in the upper trophic positions. These species are easily overfished, and a longer recovery time is needed for them to come back and more to restore their functionality on the reef. Management should calculate tradeoffs between short-term gain in lucrative fishing with the risk of losing the entire ecosystem services, or long-term gain in having a healthy and stable environment.

\section{DATA AVAILABILITY STATEMENT}

The datasets generated for this study can be found in the online repositories. The names of the repository/repositories and accession number(s) can be found below: http://dx.doi.org/10. 17632/v6ksv75gk3.1. 


\section{AUTHOR CONTRIBUTIONS}

$\mathrm{FF}$ and OA-O designed the study. IM-O, LL-D, CG-S, HP-E, MR-H, M-ÁR-Z, HV-H, and AV-Z here who contributed in gathering field data. FF analyzed the data. All authors contributed equally in drafting the manuscript.

\section{FUNDING}

This study was funded by the Ocean 5 Foundation, the Pristine Seas-National Geographic, and the Wyss Foundation. $M-A ́ R-Z$ and $A V-Z$ received partial financial support from CONACYT, project 257855 .

\section{REFERENCES}

Aburto-Oropeza, O., Ezcurra, E., Moxley, J., Sánchez-Rodríguez, A., MascareñasOsorio, I., Sánchez-Ortiz, C., et al. (2015). A framework to assess the health of rocky reefs linking geomorphology, community assemblage, and fish biomass. Ecol. Indic. 52, 353-361. doi: 10.1016/j.ecolind.2014.12.006

Alvarez-Filip, L., Estrada-Saldívar, N., Pérez-Cervantes, E., Molina-Hernández, A., and González-Barrios, F. J. (2019). A rapid spread of the stony coral tissue loss disease outbreak in the Mexican Caribbean. PeerJ. 7:e8069. doi: 10.7717/peerj. 8069

Anderson, M. J. (2001). A new method for non-parametric multivariate analysis of variance. Austr. Ecol. 26, 32-46. doi: 10.1046/j.1442-9993.2001.01070.x

Arguelles, J., Brenner, J., and Pérez-España, H. (2019). Línea Base Para el Monitoreo de los Arrecifes del Sistema Arrecifal Veracruzano (PNSAV) a Través de la Metodología AGRRA (Atlantic and Gulf Rapid Reef Assessment). Arlington, VI: The Nature Conservancy.

Beaver, C. R., and Chávez, E. A. (2007). "Reef fisheries," in Coral Reefs of the Southern Gulf of Mexico, eds J. Tunnell, E. Chávez, K. Withers, and S. Earle (College Station, TX: Texas A\&M University Press), 112-118.

Bhathal, B., and Pauly, D. (2008). "Fishing down marine food webs" and spatial expansion of coastal fisheries in India, 1950-2000. Fish. Res. 91, 26-34. doi: 10.1016/j.fishres.2007.10.022

Bonaldo, R. M., Hoey, A. S., and Bellwood, D. R. (2014). The ecosystem roles of parrotfishes on tropical reefs. Oceanogr. Mar. Biol. 52, 81-132. doi: 10.1201/ b17143

Brenner, L., Engelbauer, M., and Job, H. (2018). Mitigating tourism-driven impacts on mangroves in Cancún and the Riviera Maya, Mexico: an evaluation of conservation policy strategies and environmental planning instruments. J. Coast. Conserv. 22, 755-767. doi: 10.1007/s11852-018-0606-0

Bruno, J. F., Côté, I. M., and Toth, L. T. (2019). Climate change, coral loss, and the curious case of the parrotfish paradigm: why don't marine protected areas improve reef resilience? Ann. Rev. Mar. Sci. 11, 307-334. doi: 10.1146/annurevmarine-010318-095300

Cheal, A. J., MacNeil, M. A., Cripps, E., Emslie, M. J., Jonker, M., Schaffelke, B., et al. (2010). Coral-macroalgal phase shifts or reef resilience: links with diversity and functional roles of herbivorous fishes on the Great Barrier Reef. Coral Reefs 29, 1005-1015. doi: 10.1007/s00338-010-0661-y

Coghlan, A. R., White, R., Dawson, T. P., Irving, R. A., Zeller, D., and Palomares, M. L. D. (2017). Reconstructed marine fisheries catches at a Remote Island Group: Pitcairn Islands (1950-2014). Front. Mar. Sci. 4:320. doi: 10.3389/fmars. 2017.00320

Darimont, C. T., Fox, C. H., Bryan, H. M., and Reimchen, T. E. (2011). The unique ecology of human predators. Science $349,858-860$. doi: 10.5061/dryad.238b2

DeMartini, E. E., and Friedlander, A. M. (2004). Spatial patterns of endemism in shallow-water reef fish populations of the Northwestern Hawaiian Islands. Mar. Ecol. Prog. Ser. 271, 281-296. doi: 10.3354/meps 271281

DeMartini, E. E., Friedlander, A. M., Sandin, S. A., and Sala, E. (2008). Differences in fish-assemblage structure between fished and unfished atolls in the northern

\section{ACKNOWLEDGMENTS}

We thank Paula Ezcurra for edition and comments which greatly improved the manuscript. We thank the support from the Caribbean Craken and its crew, with special thanks to Silvana Ocaña y Manuel Victoria; ECOSUR, Universidad de Yucatán, UNAM Campus Puerto Morelos and UNAM Campus Sisal.

\section{SUPPLEMENTARY MATERIAL}

The Supplementary Material for this article can be found online at: https://www.frontiersin.org/articles/10.3389/fmars. 2020.583056/full\#supplementary-material

Line Islands, central Pacific. Mar. Ecol. Prog. Ser. 365, 199-215. doi: 10.3354/ meps07501

Diaz-Pulido, G., McCook, L. J., Dove, S., Berkelmans, R., Roff, G., Kline, D. I., et al. (2009). Doom and boom on a resilient reef: climate change, algal overgrowth and coral recovery. PLoS One 4:e5239. doi: 10.1371/journal.pone.0005239

Edgar, G. J., Stuart-Smith, R. D., Willis, T. J., Kininmonth, S., Baker, S. C., Banks, S., et al. (2014). Global conservation outcomes depend on marine protected areas with five key features. Nature 506, 216-220. doi: 10.1038/nature13022

Edwards, C. B., Friedlander, A. M., Green, A. G., Hardt, M. J., Sala, E., Sweatman, H. P., et al. (2013). Global assessment of the status of coral reef herbivorous fishes: evidence for fishing effects. Proc. R. Soc. B Biol. Sci. 281, 7-11. doi: 10.1098/rspb.2013.1835

Elton, C. S. (1927). Animal Ecology. New York, NY: The Macmillan Company.

Ferreira, D. E. L., Peret, A. C., and Coutinho, R. (1998). Seasonal grazing rates and food processing by tropical herbivorous fishes. J. Fish Biol. 53, 222-235. doi: 10.1111/j.1095-8649.1998.tb01029.x

Friedlander, A. M., Ballesteros, E., Beets, J., Berkenpas, E., Gaymer, C. F., Gorny, M., et al. (2013). Effects of isolation and fishing on the marine ecosystems of Easter Island and Salas y Gómez, Chile. Aquat. Conserv. Mar. Freshw. Ecosyst. 23, 515-531. doi: 10.1002/aqc.2333

Friedlander, A. M., Caselle, J. E., Ballesteros, E., Brown, E. K., Turchik, A., and Sala, E. (2014). The real bounty: marine biodiversity in the Pitcairn Islands. PLoS One 9:e100142. doi: 10.1371/journal.pone.0100142

Friedlander, A. M., Giddens, J., Ballesteros, E., Blum, S., Brown, E. K., Caselle, J. E., et al. (2019). Marine biodiversity from zero to a thousand meters at Clipperton Atoll (Île de La Passion), Tropical Eastern Pacific. PeerJ 7:e7279. doi: $10.7717 /$ peerj.7279

Froese, R., and Pauly, D. (2019). Fishbase. World Wide Web electronic publication Available online at: www.fishbase.org

Gil-Agudelo, D. L., Cintra-Buenrostro, C. E., Brenner, J., González-Díaz, P., Kiene, W., Lustic, C., et al. (2020). Coral reefs in the Gulf of Mexico large marine ecosystem: conservation status, challenges, and opportunities. Front. Mar. Sci. 6:807. doi: 10.3389/fmars.2019.00807

Graham, N. A. J., McClanahan, T. R., MacNeil, M. A., Wilson, S. K., Cinner, J. E., Huchery, C., et al. (2017). Human disruption of coral reef trophic structure. Curr. Biol. 27, 231-236. doi: 10.1016/j.cub.2016.10.062

Harmelin-Vivien, M. L. (2002). "Energetics and fish diversity on coral reefs," in Coral Reef Fishes, ed. P. F. Sale (San Diego, CA: Academic Press).

Hatton, I. A., McCann, K. S., Fryxell, J. M., Davies, T. J., Smerlak, M., Sinclair, A. R. E., et al. (2015). The predator-prey power law: biomass scaling across terrestrial and aquatic biomes. Science 349:aac6284. doi: 10.1126/science. aac6284

Hernández-Landa, R. C., and Aguilar-Perera, A. (2019). Structure and composition of surgeonfish (Acanthuridae) and parrotfish (Labridae: Scarinae) assemblages in the south of the Parque Nacional Arrecife Alacranes, southern Gulf of Mexico. Mar. Biodivers. 49, 647-662. doi: 10.1007/s12526-017-0841-x

Horta-Puga, G., Tello-Musi, J. L., Córdova, A., Gutiérrez-Carrillo, A., GutiérrezMartínez, J., and Morales-Aranda, A. A. (2020). Spatio-temporal variability of 
benthic macroalgae in a coral reef system highly influenced by fluvial discharge: Veracruz, Gulf of Mexico. Mar. Ecol. 41:e12596. doi: 10.1111/maec.12596

Hughes, R. N. (1980). Optimal foraging theory in the marine context. Annu. Rev. Mar. Biol. Oceanogr. 18, 423-481.

Kornicker, L. S., Bonet, F., Cann, R., and Hoskin, C. M. (1959). Alacran Reef, Campeche Bank, Mexico. Publ. Inst. Mar. Sci. 6, 1-22. doi: 10.5479/si.00775630. 137.1

Kroodsma, D. A., Mayorga, J., Hochberg, T., Miller, N. A., Boerder, K., Ferretti, F., et al. (2018). Tracking the global footprint of fisheries. Science 359, 904-908. doi: $10.1126 /$ science.aao5646

Legendre, P., and Gallagher, E. D. (2001). Ecologically meaningful transformations for ordination of species data. Oecologia 129, 271-280. doi: 10.1007/ s004420100716

Liang, C., and Pauly, D. (2017). Fisheries impacts on China's coastal ecosystems: unmasking a pervasive "fishing down" effect. PLoS One 12:e0173296. doi: 10. 1371/journal.pone.0173296

Logan, B. W., Bass, M. N., and Cebulski, D. E. (1969). Carbonate sediments and reefs, Yucatan Shelf, Mexico. Tectonic relations of Northern Central America and Western Caribbean. Am. Assoc. Pet. Geol. 11, 1-198.

MacArthur, R. H., and Pianka, E. R. (1966). On optimal use of a patchy environment. Am. Nat. 100, 603-609. doi: 10.1086/282454

MacNeil, M. A., Graham, N. A. J., Cinner, J. E., Wilson, S. K., Williams, I. D., Maina, J., et al. (2015). Recovery potential of the world's coral reef fishes. Nature 520, 341-344. doi: 10.1038/nature 14358

McClanahan, T. R. (2014). Recovery of functional groups and trophic relationships in tropical fisheries closures. Mar. Ecol. Prog. Ser. 497, 13-23. doi: 10.3354/ meps10605

McClanahan, T. R., and Graham, N. A. J. (2015). Marine reserve recovery rates towards a baseline are slower for reef fish community life histories than biomass. Proc. R. Soc. B Biol. Sci. 282:20151938. doi: 10.1098/rspb.2015.1938

McClanahan, T. R., Graham, N. A. J., Macneil, M. A., and Cinner, J. E. (2015). Biomass-based targets and the management of multispecies coral reef fisheries. Conserv. Biol. 29, 409-417. doi: 10.1111/cobi.12430

McClanahan, T. R., Graham, N. A. J., MacNeil, M. A., Muthiga, N. A., Cinner, J. E., Bruggemann, J. H., et al. (2011). Critical thresholds and tangible targets for ecosystem-based management of coral reef fisheries. Proc. Natl. Acad. Sci. U.S.A. 108, 17230-17233. doi: 10.1073/pnas. 1106861108

McClanahan, T. R., and Muthiga, N. A. (2016). Geographic extent and variation of a coral reef trophic cascade. Ecology 97, 1862-1872. doi: 10.1890/15-1492.1

McClanahan, T. R., Schroeder, R. E., Friedlander, A. M., Vigliola, L., Wantiez, L., Caselle, J. E., et al. (2019). Global baselines and benchmarks for fish biomass: comparing remote reefs and fisheries closures. Mar. Ecol. Prog. Ser. 612, 167-192. doi: 10.3354/meps12874

Mellin, C., Aaron Macneil, M., Cheal, A. J., Emslie, M. J., and Julian Caley, M. (2016). Marine protected areas increase resilience among coral reef communities. Ecol. Lett. 19, 629-637. doi: 10.1111/ele.12598

Morais, R. A., and Bellwood, D. R. (2019). Pelagic subsidies underpin fish productivity on a degraded coral reef. Curr. Biol. 29, 1521.e6-1527.e6. doi: 10.1016/j.cub.2019.03.044

Mourier, J., Maynard, J., Parravicini, V., Ballesta, L., Clua, E., Domeier, M. L., et al. (2016). Extreme inverted trophic pyramid of reef sharks supported by spawning groupers. Curr. Biol. 26, 2011-2016. doi: 10.1016/j.cub.2016.05.058

Mumby, P. J., Steneck, R. S., Edwards, A. J., Ferrari, R., Coleman, R., Harborne, A. R., et al. (2012). Fishing down a Caribbean food web relaxes trophic cascades. Mar. Ecol. Prog. Ser. 445, 13-24. doi: 10.3354/meps09450

Newman, M. J. H., Paredes, G. A., Sala, E., and Jackson, J. B. C. (2006). Structure of Caribbean coral reef communities across a large gradient of fish biomass. Ecol. Lett. 9, 1216-1227. doi: 10.1111/j.1461-0248.2006.00976.x

O'Brien, J. M., and Scheibling, R. E. (2018). Turf wars: competition between foundation and turf-forming species on temperate and tropical reefs and its role in regime shifts. Mar. Ecol. Prog. Ser. 590, 1-17. doi: 10.3354/meps12530

Odum, E. P. (1955). Fundamentals of Ecology. Minneapolis, MN: University of Minnesota.

Oksanen, J., Blanchet, F. G., Friendly, M., Kindt, R., Legendre, P., McGlinn, D., et al. (2019). vegan: Community Ecology Package. R Packag. version 2.5-6.
Paul, V., and Hay, M. (1986). Seaweed susceptibility to herbivory: chemical and morphological correlates. Mar. Ecol. Prog. Ser. 33, 255-264. doi: 10.3354/ meps033255

Pauly, D. (1995). Anecdotes and the shifting baseline syndrome of fisheries. Trends Ecol. Evol. 10:430. doi: 10.1016/S0169-5347(00)89171-5

Pauly, D., Christensen, V., Dalsgaard, J., Froese, R., and Torres, F. (1998). Fishing down marine food webs. Science 279, 860-863. doi: 10.1126/science.279. 5352.860

R Core Team (2018). R: A Language and Environment for Statistical Computing. Vienna: R Foundation Statistical Computing.

Robertson, D. R. (2001). Population maintenance among tropical reef fishes: inferences from small-island endemics. Proc. Natl. Acad. Sci. U.S.A. 98, 56675670. doi: 10.1073/pnas.091367798

Ruppert, J. L. W., Travers, M. J., Smith, L. L., Fortin, M. J., and Meekan, M. G. (2013). Caught in the middle: combined impacts of shark removal and coral loss on the fish communities of coral reefs. PLoS One 8:e74648. doi: 10.1371/ journal.pone.0074648

SEMARNAT-CONANP (2007). Programa de Conservación y Manejo Parque Nacional Arrecife Alacranes. World Wide Web electronic publication Available online at: https://simec.conanp.gob.mx/pdf_libro_pm/61_libro_pm.pdf

Smith, J. E., Brainard, R., Carter, A., Grillo, S., Edwards, C., Harris, J., et al. (2016). Re-evaluating the health of coral reef communities: baselines and evidence for human impacts across the central pacific. Proc. R. Soc. B Biol. Sci. 283:20151985. doi: 10.1098/rspb.2015.1985

Steneck, R. S., Bellwood, D. R., and Hay, M. E. (2017). Herbivory in the marine realm. Curr. Biol. 27, R484-R489. doi: 10.1016/j.cub.2017.04.021

Steneck, R. S., and Dethier, M. N. (1994). A functional group approach to the structure of algal-dominated communities. Oikos 69:476. doi: 10.2307/3545860

Tickler, D., Meeuwig, J. J., Palomares, M. L., Pauly, D., and Zeller, D. (2018). Far from home: distance patterns of global fishing fleets. Sci. Adv. 4:aar3279. doi: 10.1126/sciadv.aar3279

Trebilco, R., Baum, J. K., Salomon, A. K., and Dulvy, N. K. (2013). Ecosystem ecology: size-based constraints on the pyramids of life. Trends Ecol. Evol. 28, 423-431. doi: 10.1016/j.tree.2013.03.008

Trebilco, R., Dulvy, N. K., Anderson, S. C., and Salomon, A. K. (2016). The paradox of inverted biomass pyramids in kelp forest fish communities. Proc. R. Soc. B Biol. Sci. 283:20160816. doi: 10.1098/rspb.2016. 0816

Tunnell, J. W. (2010). Arrecifes Coralinos del Golfo de México: Caracterización y Diagnóstico. México, DF: Secretaría del Medio Ambiente y Recursos Naturales.

Tunnell, J. W., Chávez, E. A., Withers, K., and Earle, S. (2007). Coral Reefs of the Southern Gulf of Mexico. Texas, TX: Texas A\&M University Press.

Victor, B. C., and Wellington, G. M. (2000). Endemism and the pelagic larval duration of reef fishes in the eastern Pacific Ocean. Mar. Ecol. Prog. Ser. 205, 241-248. doi: 10.3354/meps205241

Vieira, C. (2020). Lobophora-coral interactions and phase shifts: summary of current knowledge and future directions. Aquat. Ecol. 54, 1-20. doi: 10.1007/ s10452-019-09723-2

Williams, I. D., Richards, B. L., Sandin, S. A., Baum, J. K., Schroeder, R. E., Nadon, M. O., et al. (2011). Differences in reef fish assemblages between populated and remote reefs spanning multiple archipelagos across the central and western pacific. J. Mar. Biol. 2011:826234. doi: 10.1155/2011/826234

Conflict of Interest: The authors declare that the research was conducted in the absence of any commercial or financial relationships that could be construed as a potential conflict of interest.

Copyright (c) 2020 Favoretto, Mascareñas-Osorio, León-Deniz, González-Salas, Pérez-España, Rivera-Higueras, Ruiz-Zárate, Vega-Zepeda, Villegas-Hernández and Aburto-Oropeza. This is an open-access article distributed under the terms of the Creative Commons Attribution License (CC BY). The use, distribution or reproduction in other forums is permitted, provided the original author(s) and the copyright owner(s) are credited and that the original publication in this journal is cited, in accordance with accepted academic practice. No use, distribution or reproduction is permitted which does not comply with these terms. 